(Published in History and Theory, 59, no. 2, 2019, pp. 293-301, online at

https://doi.org/10.1111/hith.12115)

\title{
THE HISTORIAN AS A PUBLIC MORALIST: ON THE ROMAN ORIGINS OF A SCHOLARLY PERSONA
}

Herman Paul, Leiden University

VIRTUS ROMANA: POLITICS AND MORALITY IN THE ROMAN HISTORIANS. By Catalina Balmaceda. Chapel Hill: University of North Carolina Press, 2017. Pp. xii, 297.

ABSTRACT

In her recent book, Virtus Romana, Catalina Balmaceda provides a fascinating analysis of the concept of virtus in Roman historiography. Although virtus, which translates as courage or more generally as virtue, meant different things to different Roman historians, Balmaceda shows that disagreement was never about whether historians should provide readers with examples of virtue. Historians' differences of opinion focused rather on where such models were to be found and what they should look like. This review essay summarizes Balmaceda's main arguments, raises a question about historians' own virtus, and draws some implications from the book for the study of scholarly personae. Did the persona of the historian as a public moralist, such as is known from nineteenth-century Europe, originate in ancient Rome?

Keywords: Roman historiography, Sallust, Livy, Tacitus, virtus, virtues, scholarly personae

If public moralists are authors who seek to remind their readers of their moral duties, while regarding their "failings of character as the chief source of civic as well as private woe," ${ }^{1}$ then perhaps no German historian embodied this persona better than Friedrich Christoph Schlosser. The widely read author of a Weltgeschichte für das deutsche Volk (19 vols., 18441857), Schlosser was admired and scorned alike for his "moralistic" attitude to the past.

\footnotetext{
1. Stefan Collini, Public Moralists: Political Thought and Intellectual Life in Britain, 1850-1930 (Oxford: Clarendon Press, 1991), 2.
} 
Characteristic of this moralism was a frank commitment to calling virtue and vice by their names, paired to unconcealed indignation at the wrongs of especially the rich and mighty. The extent to which Schlosser saw historians as responsible for identifying virtue and vice in the past, thereby providing present-day readers with a mirror for reflection on their own moral qualities and defects, was such that Schlosser's name came to serve as shorthand for a distinct scholarly persona: the historian as a moralist. ${ }^{2}$

Where did this persona come from? In 1842, a reviewer in the Deutsche Jahrbücher für Wissenschaft und Kunst offered a hint in calling Schlosser a "Tacitian" type of historian. ${ }^{3}$ This characterization of Schlosser drew mainly on Tacitus's early modern reputation as a "philosophical historian," who was able not just to narrate historical facts, but also to explain them as emerging out of human folly and misfortune. In the eighteenth century, Edward Gibbon had been among those praising Tacitus in precisely these terms. Whereas Gibbon believed that Livy, "more concerned to please than to instruct," had failed to offer a compelling explanation of the decline of the Roman Republic, Tacitus, who always "[fills] the soul with the most sagacious lessons," had pinpointed the causes of decline in the moral vices prevalent among the Roman aristocracy. ${ }^{4}$ This contrasting of Livy and Tacitus, in turn, had been indebted to late sixteenth-century sources. At a time when civil and religious wars had been raging through Europe, humanist authors had identified with Tacitus largely because of his perceived practical relevance. Comparing the turbulences of his own time with the decline of the Roman Republic, Justus Lipsius, for instance, had praised Tacitus's historical writing as "a theater of modern life," full of lessons in wisdom and prudence. More than any other classical historian,

\footnotetext{
2. Michael Gottlob, Geschichtsschreibung zwischen Aufklärung und Historismus: Johannes von Müller und Friedrich Christoph Schlosser (Frankfurt am Main: Peter Lang, 1989), 211-240. On scholarly personae as models of historiographical virtue, see Herman Paul, "The Virtues and Vices of Albert Naudé: Toward a History of Scholarly Personae," History of Humanities 1, no. 2 (2016), 327-338, and "The Virtues of a Good Historian in Early Imperial Germany: The Case of Georg Waitz," Modern Intellectual History 15, no. 3 (2018), 681-709.

3. [Karl Friedrich Köppen], review of Geschichte des achtzehnten Jahrhunderts und des neunzehnten bis zum Sturz des französischen Kaiserreichs by F. C. Schlosser, Deutsche Jahrbücher für Wissenschaft und Kunst 5, no. 6 (1842), 22.

${ }^{4}$. J. G. A. Pocock, Barbarism and Religion, 6 vols. (Cambridge, UK: Cambridge University Press, 1999-2015), I, 233.
} 
Tacitus had been hailed as embodying a type of scholar able to discern and explain, for the benefit of present and future readers alike, how virtue and vice determined the course of history. ${ }^{5}$

To what extent did the historical Tacitus fit this image? Can the persona of the historian as a public moralist be traced back to the author of the Histories and Annals? And how different was Tacitus from Livy, not to mention Sallust and other Roman historians, in providing readers with historical exempla of virtue and vice? Against the background of these questions, Catalina Balmaceda's fine study on the concept of virtus in Roman historiography makes fascinating reading. Although virtus (a term that roughly translates as courage or more generally as virtue) meant different things to different Roman historians, Balmaceda convincingly shows that disagreement was never about whether historians should provide their readers with examples of virtue. Historians' differences of opinion focused rather on where such models were to be found and what they should look like. In what follows, I will summarize the main arguments of Balmaceda's well-researched study, raise a question about historians' own virtus on which Balmaceda touches only in passing, and by way of conclusion return to Tacitus's modern admirers.

\section{ROMAN HISTORIANS ON VIRTUS}

Catalina Balmaceda, associate professor of ancient history at the Pontifical Catholic University of Chile, situates her book (based on an Oxford PhD thesis) in a growing body of scholarship on Roman key moral concepts such as fides, libertas, clementia, and pudicitia. Yet instead of providing, as is customary in the genre, a conceptual history of virtus as employed in a variety of literary genres - a project already undertaken by Myles McDonnell and Juhani Sarsila ${ }^{6}$-she chooses to zoom in on how virtus figures in the works of four Roman historians: Sallust, Livy, Velleius, and Tacitus. Given that these historians clearly "not only wrote history but also

5. Anthony Grafton, What Was History? The Art of History in Early Modern Europe (Cambridge, UK: Cambridge University Press, 2007), 205; Jan Waszink, "Your Tacitism or Mine? Modern and Early-Modern Conceptions of Tacitus and Tacitism," History of European Ideas 36, no. 4 (2010), 375-385, esp. 378.

6. Myles McDonnell, Roman Manliness: Virtus and the Roman Republic (Cambridge, UK: Cambridge University Press, 2006); Juhani Sarsila, Being a Man: The Roman Virtus as a Contribution to Moral Philosophy (Frankfurt am Main: Peter Lang, 2006). 
helped shape it, by endorsing specific values, creating a tradition, constructing identity, and introducing role models" (2), this enables Balmaceda to study virtus as a rhetorical figure invoked for edifying purposes in a variety of ways, depending on the authors' worldviews and the moral-political situations in which they wrote their histories of Rome. Because historical writing in Rome was never far removed from political decision-making, Balmaceda can even claim that historiographical texts enable her to examine the legitimizing functions of virtus in a period of transition from the late Republic to the early Principate. "Was virtus adapted to the new political regime, or did the new system have to include traditional forms of virtus to make itself acceptable?" (3)

Unsurprisingly, in the chapters following Balmaceda's programmatic introduction, the exemplary past plays a major role. Roman historical writing served as a magistra vitae in that it provided moral exempla, both positive and negative. In Livy's often quoted words: "What chiefly makes the study of history wholesome and profitable is this, that you behold the lessons of every kind of experience set forth as on a conspicuous monument; from these you may choose for yourself and for your own state what to imitate, from these mark for avoidance what is shameful in the conception and shameful in the result." 7 As the virtues and vices of their ancestors provided the Romans with models of public morality, historians played a crucial role in bringing these ancient models to the attention of present-day readers. ${ }^{8}$ Interestingly, however, Balmaceda shows that Sallust, Livy, Velleius, and Tacitus defined that role in different ways. Although they agreed on the exemplary function of history-writing and, more specifically, on the need to provide readers with historical models of virtus, the four historians not only differed in what they understood virtus to mean, but also in where they expected virtus to be found.

Sallust, for instance, was engaged in what Balmaceda calls a semantic broadening and social expansion of virtus (46). Virtue had originally been a preserve of the nobilitas, but Sallust, in the first century $B C E$, tried to redefine it so as to bring it within reach of homines novi like

7. Livy, Hist., 1.10, quoted after History of Rome, Books 1-2, transl. B. O. Foster (Cambridge, MA: Harvard University Press, 2015), 7.

${ }^{8}$. In this respect, ancient Roman historiography resembled historical writing in Han China: F.-H. Mutschler, "Sima Qian and His Western Colleagues: On Possible Categories of Description," History and Theory 46, no. 2 (2007), 201-209. 
himself. To that end, the politician-turned-historian tried to show, on the one hand, that vices such as luxuria and superbia had corrupted the aristocracy to such an extent that their claims to virtus had become hollow. On the other hand, Sallust's idealized portrayal of Gaius Marius, the Roman consul known as "the third founder of Rome," illustrates how firmly he believed homines novi to be able to serve as models of virtue: there is hardly a virtue in which Marius as depicted by Sallust did not excel (66). Sallust thus tried to adapt the ancient concept of virtus to a sociopolitical context in which privileges of birth met increased competition from virtuous deeds as markers of good character (42). In Balmaceda's words, "Sallust's redefinition of virtus is a fine balance between reinforcing the concept's core and changing it: an old value is dressed in a new sensibility" (81).

Livy, some decades younger than Sallust, can be read as responding to a key element in his predecessor's work: the idea that virtus among the nobilitas had been in decline, especially after the destruction of Carthage in 146 BCE. "If there has been change and decline as Sallust claims, and if history is to provide exempla, as Sallust also states, then the logical step is to seek those exempla in the period before decline started" (84). Although Livy did not deny that homines novi could possess virtue, he more often attributed virtus to Roman soldiers, thereby reinforcing the traditional meaning of virtus as courage in war (92). For a work of history that covers Roman history from its earliest beginnings ("ab urbe condita"), this is perhaps not very surprising: Livy had more battles to narrate than Sallust. However, when Livy described the virtus militum of Roman soldiers (and, occasionally, their enemies), he also did so with an eye to the present. Livy, too, provided his readers with examples of virtue, upholding virtus as an "aspirational ideal" to Romans in the late Republic (126). Still, the military connotations remained stronger than in Sallust, even in Livy's discussion of the opening of the consulship to plebeian "new men." In Balmaceda's reading, Livy interpreted this conflict of the orders as a fight for freedom - a quarrel against injustice that required virtus not unlike the bravery expected on the battlefield $(115,117)$.

Velleius, a homo novus with extensive military and political experience who authored a Compendium of Roman History, is a less well-known historian than Sallust or Livy. Although he resembled the former in emphasizing that virtus is achieved by merits instead of birth (140), his role in Balmaceda's book is mainly that of a counterweight to Sallust. Whereas the late Republican historian perceived the aristocracy as suffering from moral corruption, Velleius took the more optimistic view that even an emperor like Tiberius managed to keep Roman 
virtus alive. So instead of highlighting discontinuities between the Republic and the Principate, Velleius argued that virtus was still possible, perhaps even more attainable than it had been before. "Now, when peace is spread throughout the empire and its head is a model of virtus, Romans - aristocrats and homines novi-can practice it openly and without fear" (156).

This, of course, was not exactly how Tacitus, the fourth and final historian singled out for discussion in Virtus Romana, evaluated the moral situation of his time. Tacitus's tone was grimmer. He used the word virtus much more sporadically than his predecessors did (244). Still, according to Balmaceda, this does not warrant the conclusion that Tacitus questioned the possibility of virtue under the Principate. She reads him as redefining virtus, not by applying the old word to new situations, as Sallust had done, but by telling a story of transformation. "It is as if virtus cannot be shown as it used to-mainly in courageous acts in defense of the state-but new expressions of it can be found in less public or less conspicuous manifestations, such as resistance, moderation, and constancy" (244). Challenging the standard view that Tacitus depicted the Empire solely in terms of vices and corruption, Balmaceda argues that virtues like constantia and fides constituted what Tacitus believed virtus could be under new political circumstances. Even if the Principate marked a break in Roman history, symbolized by its revaluation of traditional Roman values, "the core of being Roman remained. It only had to be exercised in a different way" (224).

As these brief chapter summaries suggest, Balmaceda does not exactly tell a linear tale. Although her four historians all attached great value to virtus, the different uses to which they put the term do not allow for simple stories of development. Instead, Balmaceda suggests that virtus was an essentially contested concept, which as such was in constant need of interpretation and application. Precisely because virtus was charged with a host of different meanings and emotions, historians played a welcome role in delineating the concept and illustrating it with real-life examples. "They were," as Balmaceda concludes, like "guides who showed the way" (243).

\section{THE HISTORIAN'S OWN VIRTUS}

Although I am not enough of a specialist in Roman historiography to be able to judge the philological merits of Balmaceda's interpretations, ${ }^{9}$ her book strikes me as a lucid analysis of a

${ }^{9}$. I refer the interested reader to Jyri Vaahtera's review in The Classical Review 68, no. 2 
key category in Roman historical-moral-political discourse and as a powerful reminder that historical-moral-political reflection in Rome can never be divided into separate genres: there was no Roman historical writing that did not, in one way or another, offer moral guidance and engage in political campaigning. Also, so far as I can see, the chapter on Tacitus adds important nuance to the received wisdom that Tacitus offered a largely dystopian view of moral culture in the Roman Empire. Yet there is one question that I would like to bring up.

Following up on a suggestion by Elizabeth Rawson ("Historiography had long been seen almost as an extension of public life $\left.{ }^{\prime 10}\right)$, Balmaceda argues that historians were among those who profited from the social expansion and semantic broadening of virtus mentioned above. When virtus could be displayed, not merely on the battlefield, but in all sorts of service to the public good, then historians might well claim virtus by recording the deeds of the ancestors (44). Balmaceda sees this most clearly in Sallust, who argued that historians could demonstrate virtus by working hard and diligently and, interestingly, by bravely bearing potential reproaches of readers who suspect that criticism of the shortcomings of historical actors emerges out of envy or malevolence (53). If this passage from Sallust's Bellum Catilinae is discussed in only a couple of lines, the conclusion that Balmaceda draws from it, in the last paragraph of her book, is hardly more elaborated: "The need for interpretation, organization, and selection; for matching words and deeds; and for truthful and imaginative reconstruction of the events of the past make the historian's virtus an essential element of his job" (247). What virtus exactly required from historians and why it was important to them remains unclear.

Yet the question matters: What, if anything, was virtuous about identifying virtus, or the lack thereof, in Rome's historical record? This is a relevant question not merely because modern and early modern historians alike often engaged in explicit or implicit dialogue with classical authors in articulating their views on "the highest virtue of the historian."11 (Even the

(2018), 516-518 and Paul Belonick's review in the Bryn Mawr Classical Review (http://bmcr.brynmawr.edu/2018/2018-06-23.html).

10. Elizabeth Rawson, Intellectual Life in the Late Roman Republic (London: Duckworth, 1985), 91.

11. See, for example, Ulrich Muhlack, "Herodotus and Thucydides in the View of NineteenthCentury German Historians," in Thucydides and the Modern World: Reception, Reinterpretation and Influence from the Renaissance to the Present, ed. Katherine Harloe and Neville Morley (Cambridge, UK: Cambridge University Press, 2012), 179-209; Tucidide nella storiografia 
phrases "highest virtue" and "highest duty" as used in modern historiographical reflections have somewhat of a Tacitian ring to them. ${ }^{12}$ ) More important, in the context of Balmaceda's book, is that moral evaluation of historical agents is what Greek and Roman audiences expected from a virtuous historian. As T. James Luce argues in a well-known article, failure to point out what was praiseworthy and blameworthy in the past was generally interpreted as a moral defect on the historian's part. It was the mark of a good character to call good and evil by their names. Consequently, identifying virtus in the past was part and parcel of what it meant to be virtuous in the eyes of present and future readers. "In his writing the historian's own character [was] as important as the character of the personage appearing in his pages, perhaps more so."13

Arguably, this expectation of readers judging the historian's moral integrity helps explain why Plutarch saw Herodotus's attribution of military or political successes to causes other than personal courage as sufficient reason for declaring Herodotus "guilty of malice" and why Polybius thought that Timaeus displayed an "utter lack of decency" by falsely accusing Demochares of immoral conduct. ${ }^{14}$ In criticizing their predecessors, these Greek historians saw undeserved praise or blame as sufficient ground for calling the historian's character into question. Now can the same be said about Roman historians? Could a similar concern about the historian's own virtus explain why Sallust, speaking about the courage required for historical writing, immediately thought of future readers and their assessments of the historian's

moderna, ed. Claudia Montepaone (Naples: Morano, 1994); J. H. M. Salmon, “Cicero and Tacitus in Sixteenth-Century France," American Historical Review 85, no. 2 (1980), 307-331; Peter Burke, "A Survey of the Popularity of Ancient Historians, 1450-1700," History and Theory 5, no. 2 (1966), 135-152.

12. On "history's highest function" in Tacitus's Annales, see William Turpin, "Tacitus, Stoic Exempla, and the praecipuum munus annalium," Classical Antiquity 27, no. 2 (2008), 359-404; A. J. Woodman, Tacitus Reviewed (Oxford: Clarendon Press, 1998), 86-103.

13. T. J. Luce, "Ancient Views on the Causes of Bias in Historical Writing," Classical Philology 84, no. 1 (1989), 21.

14. Plutarch, De Herod. Mal., 7, quoted after The Malice of Herodotus, transl. Anthony Bowen (Warminster, UK: Aris \& Phillips, 1992), 27; Polybius, Hist., 12.13, quoted after The Histories: Books 9-15, transl. W. R. Paton, rev. Frank W. Walbank and Christian Habicht (Cambridge, MA: Harvard University Press, 2011), 381. 
character? Did Roman historians pay extensive attention to the virtus (or lack thereof) of historical agents partly also in order to demonstrate their own virtus?

If indeed historians "wished to be seen as competent to judge both men and deeds," as John Marincola puts it, ${ }^{15}$ then this desire for recognition would have merited discussion in Balmaceda's book, if only because it complicates the argument that historians had mainly political reasons for highlighting the virtutes of their Roman ancestors. Perhaps they sought to serve the res publica by providing positive and negative exempla, but also, at the same, to fashion themselves as possessing virtus.

\section{MODERN AFTERLIVES}

If we return, by way of conclusion, to the modern era, this idea of historians showing their strength of character by assessing the moral qualities and flaws of historical actors turns out to have been more persistent than one might expect. Although the practice of providing readers with direct moral exempla was gradually replaced by other modes of endowing the past with moral significance, ${ }^{16}$ the idea that keeping silent about the moral merits and defects of people in the past amounted to a character weakness was a legacy of Roman historiography that endured, if not prominently, at least conspicuously until well into the nineteenth century. When in 1840 an anonymous reviewer complained about Leopold von Ranke's lack of "moralreligious character," this was because the Berlin historian failed to judge the past in the light of "all what is holy, true, and beautiful."17 Likewise, another German critic, writing in the 1850s, considered Ranke to be less than an ideal historian, given that political-moral judgment was indispensable for authors seeking to "ennoble and educate" their readers instead of merely "entertaining" them. (In the gendered language of the time, this amounted to saying

\footnotetext{
${ }^{15}$. John Marincola, Authority and Tradition in Ancient Historiography (Cambridge, UK: Cambridge University Press, 1997), 164.
}

${ }^{16}$. On the gradual disappearance of the historia magistra vitae tradition in post-Enlightenment Europe, see Reinhart Koselleck's classic essay, "Historia Magistra Vitae: The Dissolution of the Topos into the Perspective of a Modernized Historical Process," in Koselleck, Futures Past: On the Semantics of Historical Time, transl. Keith Tribe (New York: Columbia University Press, 2004), 26-42.

17. "Die Reformation in französischer und deutscher Auffassung," Blätter für literarische Unterhaltung (1840), 818. 
that Ranke lacked "manly earnestness." ${ }^{18}$ ) How could objectivity be hailed as a virtue, wondered a third critic, if it practically amounted to a "horrifying insensitivity to the difference between justice and injustice, virtue and slander, merit and crime?"19 As late as 1890, Julius Langbehn, the widely read author of Rembrandt als Erzieher, castigated Rankean historical studies for a "lack of spiritual character," because they hardly ever showed something like a "pathos of conviction."20

What these examples illustrate is that critics of a historiographical tradition inspired mainly by Thucydides deliberately invoked the Roman topos of character nobility demonstrated by frank moral assessment of past rights and wrongs. ${ }^{21}$ Whereas Ranke became a symbol of Thucydides-style political history, the "Tacitian" Schlosser lent his name to an alternative tradition that prided itself on cultivating "warm-hearted character" and "moral earnestness." 22 On the one hand, this testifies to a transition that Arnaldo Momigliano has dated to the years around 1860: modern historians began to replace classical ones as models of virtue, if only because historians increasingly preferred to inscribe themselves in national historiographical narratives. ${ }^{23}$ On the other hand, the kind of virtues attributed to Schlosser clearly demonstrate that the Roman legacy had not disappeared entirely. Among Schlosser's admirers at least, the persona of the historian as a public moralist was kept alive, if only to remedy the perceived

18. Julian Schmidt, Geschichte der deutschen Nationalliteratur im neunzehnten Jahrhundert, 2 vols. (Leipzig: Friedrich Ludwig Herbig, 1853), I, 322.

19. Johannes Scherr, Allgemeine Geschichte der Literatur, 4th ed., 2 vols. (Stuttgart: Carl Conradi, 1872), II, 285.

20. [Julius Langbehn], Rembrandt als Erzieher: Von einem Deutschen (Leipzig: C. L. Hirschfeld, 1890), 69.

21. On Barthold Georg Niebuhr, Ranke, Wilhelm Roscher, and Eduard Meyer as "Thucydidean Germans," see Klaus Meister, Thukydides als Vorbild der Historiker: Von der Antike bis zur Gegenwart (Paderborn: Ferdinand Schönigh, 2013), 167-189 and Franciso Murari Pires, "Thucydidean Modernities: History between Science and Art," in Brill's Companion to Thucydides, ed. Antonios Rengakos and Antonis Tsakmakis (Leiden: Brill, 2006), 811-837.

22. Scherr, Allgemeine Geschichte der Literatur, II, 280, 281.

23. Arnaldo Momigliano, "The Place of Ancient Historiography in Modern Historiography," Entretiens sur l'Antiquité classique 26 (1980), 144. 
defects of Rankean historical studies. ${ }^{24}$

Despite Momigliano's efforts at unearthing "the classical foundations of modern historiography," 25 students of modern historical studies have largely overlooked this classical heritage. By and large, they have followed Ranke's students in emphasizing historiographical innovation over indebtedness to classical models, thereby ignoring that Ranke deeply immersed himself in ancient Greek and Roman historiography before turning his attention to early modern Venetian relazioni-even though such a classical orientation was more rule than exception in a culture where ancient historians were required student reading and Thucydides and Tacitus still represented historians' highest aspirational ideals. ${ }^{26}$ More specifically, historians of historiography have largely disregarded the extent to which "ancient masters" continued to serve as models of inspiration for historians dissatisfied with the persona of the modern historical critic. ${ }^{27}$

Therefore, despite the fact that Virtus Romana is targeted primarily at classicists, even historians of modern historical studies can read Balmaceda's study with much profit. Understanding what virtus meant to ancient Roman historians contributes to elucidating the classical (not just Tacitian) origins of the persona of the historian as a public moralist.

24. Herman Paul, "Ranke vs Schlosser: Pairs of Personae in Nineteenth-Century German Historiography," in How to Be a Historian: Scholarly Personae in Historical Studies, 1800-2000, ed. Herman Paul (Manchester, UK: Manchester University Press, 2019), 36-52.

25. Arnaldo Momigliano, The Classical Foundations of Modern Historiography (Berkeley: University of California Press, 1990).

26. On Ranke's immersion into classical historiography, see Grete Freytag, "Leopold von Ranke und die römische Geschichte," PhD thesis, Philipps University of Marburg, 1966, 20-34. The prominence of classical models in early nineteenth-century Germany was such that Johannes von Müller was routinely referred to as the "German Tacitus" and Niebuhr could not pay Ranke a greater compliment than calling him a "present-day Thucydides."

27. Johann Gustav Droysen invoked the "ancient masters" in a letter to Wilhelm Arendt (May 8, 1857, in Briefwechsel 1829-1884, ed. Rudolf Hübner, 2 vols. [Osnabrück: Biblio-Verlag, 1929], II, 451), following up on an earlier letter in which he had said to identify with "every decent historian since Thucydides" rather than with "the Rankean school" and the kind of scholarship fostered by the Monumenta Germaniae Historica (Droysen to Arendt, March 20, 1857, ibid., II, 442). 